\title{
THE SENSITIVITY IN VITRO OF THE PROVIDENCE GROUP OF ENTERIC BACTERIA TO 14 ANTIBIOTICS AND NITROFURANTOIN
}

\author{
BY \\ J. E. MIDDLETON \\ From the Louis Jenner Laboratory, St. Thomas's Hospital and Medical School, London
}

(RECEIVED FOR PUBLICATION JANUARY 8, 1958)

During the course of an investigation into the antibiotic sensitivity of strains of the Proteus group of bacteria isolated from infections of the urinary tract (Middleton, 1957) a few strains of the Providence group were also examined. This group of the Enterobacteriaceae called type 29911 by Stuart, Wheeler, Rustigian, and Zimmerman (1943), and named Providence by Kauffmann (1951), has close affinities in many characteristics with the Proteus group (Singer and Bar-Chay, 1954), and a similarity between strains of the two groups was found here in their common resistance to many antibiotics in vitro. An opportunity has since arisen to study a larger number of Providence strains and a relationship has also been demonstrated between the biochemical types of Providence strains and their antibiotic spectra.

\section{Material and Methods}

Forty Providence strains were examined. Nine were isolated in this laboratory, of which eight were from urine and one from faeces. The 31 other strains were obtained from Dr. K. P. Carpenter. Director of the Dysentery Reference Laboratory. Central Public Health Laboratory, Colindale, London. These were recently isolated organisms which had been sent there from various centres in Britain and the Commonwealth; one was from urine, 29 from faeces, and the source of one strain was unknown.

The identification of the strains isolated in this laboratory was based on the criteria described by Kauffmann (1954). This identity was kindly confirmed by Dr. Carpenter, who, in addition, classified these strains, and those supplied by her, into the biochemical subdivisions described by Ewing, Tanner, and Dennard (1954).

The dried disc technique described by Fairbrother and Jennings (1955) was used for testing the sensitivity of the strains to penicillin ( 2.5 units), novobiocin $(20 \mu \mathrm{g}$.$) , bacitracin (10 \mathrm{u}$.$) , erythromycin (10 \mu \mathrm{g}$.$) ,$ spiramycin $(60 \mu \mathrm{g}$.), oleandomycin $(10 \mu \mathrm{g}$.), streptomycin $(80 \mu \mathrm{g}$.$) , neomycin (50 \mu \mathrm{g}$.$) , soframycin (50 \mu \mathrm{g}$.$) ,$ tetracycline $(100, \mathrm{~g}$.$) . chlortetracycline (100, \mathrm{~g}$.$) ,$ oxytetracycline $(100 \mu \mathrm{g}$.$) , chloramphenicol (100 \mu \mathrm{g}),$. polymyxin $(500 \mathrm{u}$.$) , and nitrofurantoin 10,000 \mu \mathrm{g}$.). (The concentration of each drug per paper disc or 은 test tablet is given in brackets.) A zone of inhibition of growth $10 \mathrm{~mm}$. or more in diameter $\vec{z}$ was considered to indicate sensitivity to the antibiotics, the discs or test tablets being $5 \mathrm{~mm}$. in diameter. Any inhibition of growth round the nitro- $\vec{e}$ furantoin test tablet was taken to indicate that the organism was sensitive to the drug.

A few strains were also tested by the serial dilutiono technique against streptomycin, tetracycline, and chloramphenicol. A standard drop $(0.02 \mathrm{ml}$.) of aō $1 / 10,000$ dilution of an overnight broth culture was added to a series of tubes containing $1 \mathrm{ml}$. of nutrient $\stackrel{\bar{Q}}{\Omega}$ broth plus doubling dilutions of each of the anti- $\overrightarrow{\vec{P}}$ biotics separately. These results, as also those of theo disc tests, were read after about 18 hours' incubation at $37^{\circ} \mathrm{C}$.

\section{Results}

The biochemical classification of the 40 Provi-o dence strains is shown in Table I. All the strains isolated from urinary infections were of Ewing's. biotype 27 .

TABLE I BIOCHEMICAL CLASSIFICATION OF 40 PROVIDENCE

\begin{tabular}{|c|c|c|c|}
\hline $\begin{array}{c}\text { Ewing, Tanner, } \\
\text { and Dennard } \\
\text { Biochemical Group }\end{array}$ & $\begin{array}{l}\text { No. of } \\
\text { Strains }\end{array}$ & $\begin{array}{l}\text { Ewing, Tanner, } \\
\text { and Dennard } \\
\text { Biotype }\end{array}$ & $\begin{array}{l}\text { No. of } \\
\text { Strains }\end{array}$ \\
\hline 1 & 20 & $\begin{array}{l}1 \\
4 \\
5 \\
6\end{array}$ & $\begin{array}{l}5 \\
4 \\
7 \\
4\end{array}$ \\
\hline 2 & 20 & $\begin{array}{l}21 \\
27\end{array}$ & $\begin{array}{r}7 \\
13\end{array}$ \\
\hline
\end{tabular}

All the 40 strains were resistant to penicillin, novobiocin, bacitracin, erythromycin, spiramycin $\frac{\bar{D}}{\mathrm{D}}$ and oleandomycin. All were sensitive to neo mycin, soframycin, and nitrofurantoin. Fifteer $\mathbb{B}$ per cent. of strains belonging to Ewing's biog chemical group 1 and $10 \%$ of Ewing's bio 
TABLE II

BACTERIAL SENSITIVITY IN VITRO OF 40 PROVIDENCE STRAINS (DISC TEST)

\begin{tabular}{|c|c|c|c|c|c|c|c|}
\hline \multirow{2}{*}{ Organism } & & \multirow{2}{*}{$\begin{array}{l}\text { No. of } \\
\text { Strains Tested }\end{array}$} & \multicolumn{5}{|c|}{$\begin{array}{l}\text { Percentage Sensitive to Certain Antibiotics and Average Diameter of Zone of Inhibition } \\
\text { of Growth (mm.) of All Strains }\end{array}$} \\
\hline & & & Streptomycin & Tetracycline & Chlortetracycline & Oxytetracycline & Chloramphenicol \\
\hline $\begin{array}{cc}\text { Biochemical Group } & 1 \\
& \end{array}$ & $\cdots$ & $\begin{array}{l}20 \\
20\end{array}$ & $\begin{array}{c}100 \\
11 \cdot 7(10-14)^{*} \\
10 \\
6 \cdot 7(5-11)\end{array}$ & $\begin{array}{c}45 \\
9.6(7-15) \\
0 \\
6.4(5-8)\end{array}$ & $\begin{array}{c}15 \\
8 \cdot 7(6-13) \\
0 \\
6 \cdot 5(5-8)\end{array}$ & $\begin{array}{c}75 \\
11 \cdot 0(6-16) \\
10 \\
7 \cdot 1(5-12)\end{array}$ & $\begin{array}{c}100 \\
15 \cdot 6(11-20) \\
15 \\
7 \cdot 8(5-11)\end{array}$ \\
\hline
\end{tabular}

* Limits of inhibition of growth in brackets. Disc diameter $5 \mathrm{~mm}$.

chemical group 2 strains were sensitive to polymyxin. With streptomycin, the tetracycline antibiotics, and chloramphenicol a difference in sensitivity between strains of biochemical groups 1 and 2 was found, as is shown in Table II. Strains of the former group were mainly sensitive and those of the latter group resistant to these antibiotics. There was no marked variation from this general pattern with individual strains of the biotypes composing these biochemical groups, except that all biotype 1 strains tested were resistant to the tetracycline analogues; biotype 21 strains were all uniformly resistant to streptomycin, the tetracycline drugs, and chloramphenicol. The average diameters, and the limits, of the zones of inhibition of growth found in the disc tests, which were also recorded in Table II, show that the difference in sensitivity between the two biochemical groups was marked. Relatively large zones of inhibition of growth were obtained with biochemical group 1 strains, whereas with biochemical group 2 strains either no inhibition of growth occurred or only small zones were produced. This difference was confirmed by the results of the serial dilution tests (Table III), and was more than 16 -fold with each antibiotic.

TABLE III

BACTERIAL SENSITIVITY IN VITRO (TEST TUBE)

\begin{tabular}{|c|c|c|c|c|}
\hline \multirow{2}{*}{\multicolumn{2}{|c|}{$\begin{array}{l}\text { Providence Strain } \\
\text { (Typical) }\end{array}$}} & \multicolumn{3}{|c|}{$\begin{array}{c}\text { Minimum Inhibitory Concentration of } \\
\text { Antibiotic }(\mu \mathrm{g} . / \mathrm{ml} .)\end{array}$} \\
\hline & & \multirow{2}{*}{$\begin{array}{c}\begin{array}{c}\text { Strepto- } \\
\text { mycin }\end{array} \\
31\end{array}$} & \multirow{2}{*}{$\begin{array}{r}\begin{array}{c}\text { Tetra- } \\
\text { cycline }\end{array} \\
3.9\end{array}$} & \multirow{2}{*}{$\begin{array}{c}\begin{array}{c}\text { Chloram- } \\
\text { phenicol }\end{array} \\
7.8\end{array}$} \\
\hline $\begin{array}{l}\text { Biochemical } \\
\text { Group 1 }\end{array}$ & Biotype 6 & & & \\
\hline $\begin{array}{l}\text { Biochemical } \\
\text { Group 2 }\end{array}$ & $\begin{array}{ll},, & 21 \\
, \quad 27\end{array}$ & $\begin{array}{l}>500 \\
>500\end{array}$ & $\begin{array}{r}>500 \\
250\end{array}$ & 250 \\
\hline
\end{tabular}

\section{Discussion}

Brooke (1951) tested the antibiotic sensitivity of 35 Providence strains isolated from urine. These were all resistant to penicillin and sulphathiazole, and most of the strains were resistant or only slightly sensitive to streptomycin, chlortetracycline, oxytetracycline, and chloramphenicol. Biochemically these strains resemble strains of Ewing's biochemical group 2 and especially biotype 21 , although from the details given by Brooke it is not possible to reclassify the organisms precisely under Ewing's system. Lutz and Hofferer (1955) examined 16 strains; all were sensitive to neomycin and soframycin, and 11 were sensitive to chloramphenicol, but all were resistant to streptomycin and the tetracycline antibiotics. Biochemically 14 of these strains correspond to Ewing's biotype 4 and the other two to biotype 27. The findings of the present investigation are in general agreement with these results, except that the four strains of biotype 4 which were tested here were more sensitive to streptomycin and the tetracycline drugs than those of Lutz and Hofferer (1955).

Lutz and Hofferer showed that Providence strains as a whole have a different antibiotic spectrum from that of the four Proteus species, each of which has a relatively distinct pattern of sensitivity to antibiotics, as has been found by these authors and Poole (1954) and Potee, Wright, and Finland (1954). This has in general been confirmed, but if the antibiotic spectra of the strains of Ewing's biochemical groups 1 and 2 are considered separately they show some resemblance to the antibiotic spectra of strains of $P$. morganii and $P$. rettgeri. Strains of these Proteus species are more often either uniformly sensitive or resistant to streptomycin, the tetracycline antibiotics, and chloramphenicol than those of $P$. mirabilis and $P$. vulgaris. There is also a very close similarity between them and Providence strains in their susceptibility to other antibiotics, and it is these Proteus species which Providence is most like in other respects. Providence strains are not infrequently confused with the shigellae, and biochemical group 1 strains have an antibiotic spectrum similar to that of the latter genus. However, Proteus and Providence are generally resistant to polymyxin, whereas the shigellae are very sensitive to this antibiotic as was shown by 
Felsenfeld, Volini, Ishihara, Bachman, and Young (1950).

It is recognized that strains from only six of the 31 biotypes described by Ewing et al. (1954) have been studied, but, since these six biotypes comprised $71 \%$ and $62.7 \%$ respectively of strains of the biochemical groups 1 and 2 formulated by these authors during their study of 611 strains, the results are considered to be reasonably representative.

It is interesting that all the nine strains isolated from urine belonged to biotype 27. It is possible that some of the eight found in this laboratory were examples of cross-infection, but it is unlikely that they all were, since they were isolated over a period of a number of years and some were from different hospitals. The 35 strains from urine reported by Brooke (1951) were also probably of biochemical group 2. The biochemical classification of the 15 strains from urine which were studied by Ewing et al. (1954) is not given by the authors, but from the details recorded of their antigenic grouping it is possible that these strains also were of biochemical group 2. On the other hand the four strains isolated from urine by Lutz and Hofferer (1955) were equally divided between the two biochemical groups. However, since only $13 \%$ of the 611 Providence strains, from all sources, examined by Ewing et al. (1954) were of biochemical group 2, and only one was biotype 27, the above findings suggest a predilection of organisms of this biochemical group for the urinary tract.

On the basis of the sensitivity tests in vitro there is as yet a paucity of chemotherapeutic agents available for use in infections due to some Providence strains, and especially in systemic and urinary infections. This may be in part the explanation of the more frequent isolation of the most resistant strains from the urine. All the cases observed here had infections complicated by other disease of the urinary tract, and it is such

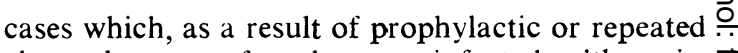
chemotherapy, often become infected with resistant organisms.

\section{Summary}

The sensitivity in vitro of 40 strains of the $\frac{\sigma}{\sigma}$ Providence group of enteric bacteria to 14 anti- $\varrho$ biotics and nitrofurantoin has been determined. क

The strains had been classified biochemically $\overrightarrow{0}$ into the biochemical groups and biotypes described by Ewing et al. (1954).

The individuality of the antibiotic spectrum of this group as a whole has been confirmed, but? strains of the biochemical groups 1 and 2 differed $\overrightarrow{ }$ in their sensitivity to some antibiotics and con- $\omega$ sidered separately showed a resemblance to strains of $P$. morganii and $P$. rettgeri in this respect.

All the strains isolated from urine were of bio- $\frac{\text { O }}{-}$ chemical group 2. A similar trend in the predilec- $\vec{z}$ tion of strains of this biochemical group for the urinary tract has been found on examining the reports of other authors.

There is as yet a paucity of chemotherapeutic agents available for use in infections due to some Providence strains, and especially in systemic and urinary infections.

I am most grateful to Dr. K. P. Carpenter for providing most of the organisms examined and for classifying them biochemically.

\section{REFERENCES}

Brooke, M. S. (1951). Acta path. microbiol. scand., $29,1$. Ewing, W. H., Tanner, K. E., and Dennard, D. A. (1954). J. infect.

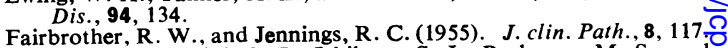
Felsenfeld, O., Volini, I. F., Ishihara, S. J., Bachman, M. S., and:

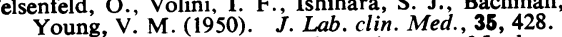

Kauffmann, F. (1951). Enterobacteriaceae. Munksgaard, Copen 3. hagen. Ibid.

Lutz, A., and Hofferer, M. J. (1955). Rev. Immunol. (Paris), 19, 69 윽 Middleton, J. E. (1957). Brit. med. J., 2, 497.

Poole, J. C. F. (1954). J. clin. Path., 7, 315. (1954). J. Lab. clin. 으 Med., 44, 463.

Singer, J., and Bar-Chay, J. (1954). J. Hyg. (Lond.), 52, 1.

Stuart, C. A., Wheeler, K. M., Rustigian, R., and Zimmerman, A (1943). J. Bact., 45, 101. 